\title{
LEPROSY CONTROL IN UGANDA DURATION OF TREATMENT OF INPATIENTS AND OUTPATIENTS
}

by J. A. Kinnear Brown, B.SC, M.D., M.R.C.S., D.T.M.

Specialist Leprologist, Uganda

and W. M. BLENSKA, M.B., B.S., D.T.M. \& H.

Medical Officer, Buluba and Nyenga Leprosaria

The Buluba and Nyenga Leprosaria are in Southern Uganda close to the shores of Lake Victoria and within 25 miles of each other. They are under the same administration so that the methods of treatment and the criteria adopted before discharge are identical. The majority of patients are of the Baganda or Basoga peoples, but there is a sprinkling of related tribes from adjacent territories. Together the two settlements accommodate between 500 and 600 inpatients. They have each a very large outpatient clinic. Treatment is mainly by oral diaminodiphenylsulphone.

Since January 1957, 410 patients have been discharged free from symptoms and all signs of active disease. They had all been bacteriologically negative to repeated examinations for at least one year. Table I shows the duration of treatment in years before discharge. The numbers are classified under the various disease types and arranged under inpatients and outpatients.

TABLE I

Duration of Treatment of Discharged Patients-In Years (Number of patients)

\begin{tabular}{|c|c|c|c|c|c|}
\hline Туре & $2-3$ & 3-4 & $4-5$ & $\begin{array}{c}\text { More than } \\
\mathbf{5}\end{array}$ & TOTAL. \\
\hline \multicolumn{6}{|l|}{ TUBERCULOII) } \\
\hline Inpatients & 9 & 9 & 22 & 15 & 55 \\
\hline Outpatients & 9 & 26 & 55 & 56 & 146 \\
\hline \multicolumn{6}{|l|}{ INDETERMINATE } \\
\hline Inpatients & 13 & 12 & 7 & 7 & 39 \\
\hline Outpatients & 7 & 21 & 37 & 43 & 108 \\
\hline \multicolumn{6}{|l|}{ DIMORPHOUS } \\
\hline Inpatients & 0 & 1 & 0 & 1 & 2 \\
\hline Outpatients & 1 & 6 & 1 & 6 & 14 \\
\hline \multicolumn{6}{|l|}{ LEPROMATOUS } \\
\hline Inpatients & & 2 & 2 & 11 & 15 \\
\hline Outpatients & 3 & 5 & 6 & 17 & 31 \\
\hline \multicolumn{6}{|l|}{ TOTAL } \\
\hline \multirow{3}{*}{ Outpatients } & 22 & 24 & 31 & 34 & 111 \\
\hline & 20 & 58 & 99 & 122 & 299 \\
\hline & 42 & 82 & 130 & 156 & 410 \\
\hline
\end{tabular}

Table II expresses the results of Table I in percentages to make comparison easier. As the lepromatous and dimorphous groups are small they have been put together. 
TABLE II

Duration of Treatment of Discharged Patients-In Years (Percentages of total)

\begin{tabular}{|c|c|c|c|c|}
\hline Type & $2-3$ & $3-4$ & $4-5$ & $\begin{array}{c}\text { More than } \\
5\end{array}$ \\
\hline \multicolumn{5}{|c|}{ TUBERCULOII) } \\
\hline Inpatients & 16 & 16 & 40 & 27 \\
\hline Outpatients & 6 & 18 & 38 & 38 \\
\hline \multicolumn{5}{|c|}{ INDETERMINATE } \\
\hline Inpatients & 33 & 31 & 18 & 18 \\
\hline Outpatients & 6 & 19 & 34 & 40 \\
\hline \multicolumn{5}{|c|}{ DIMORPHOUS and } \\
\hline \multicolumn{5}{|c|}{$\begin{array}{l}\text { LEPROMATOUS } \\
\text { LPA }\end{array}$} \\
\hline Inpatients & 0 & 18 & 12 & 71 \\
\hline Outpatients & 9 & 24 & 16 & 51 \\
\hline \multicolumn{5}{|l|}{ ALL. TYPES } \\
\hline Inpatients & 20) & 22 & 28 & 31 \\
\hline Outpatients & 7 & 19 & 33 & 41 \\
\hline
\end{tabular}

The percentages of discharges among the lepromatous and dimorphous groups in the first four years almost suggest that for them outpatient treatment is the method of choice, but it has to be remembered that besides being disproportionately smaller than the other groups those who are allowed to attend as outpatients are the early and mild cases. The difference between these inpatients and outpatients is therefore due to the manner of selection.

Patients with the tuberculoid and indeterminate types of leprosy formed seven-eights of the total discharges. Despite the fact that inpatients are drawn from the more advanced or more seriously ill cases their discharge rate under four years was significantly higher than that for those attending as outpatients. Regularity and continuity of treatment cuts down the period of treatment.

The introduction of drugs that can be administered more easily than the traditional hydnocarpus oil and that are more effective has tended towards an oversimplification of some of the issues involved. It is a great temptation to open clinics for those who can attend and sit back and feel that that is the end of the problem. In the conditions of East Africa it matters little whether the treatment is oral once or twice weekly or parenteral once each fortnight, the ability of patients to travel in all kinds of weather decides whether their treatment will be irregular or continuous. A fluctuating blood level of circulating sulphone means a longer period before cure, a longer period before the patient is uninfectious and a better chance for the bacillus to become drug resistant.

The figures in this report are not put forward as an argument for the extension or multiplication of leprosaria, but to emphasise the importance of treatment villages built by the community to enable the more infectious and those who live at a distance to obtain adequate treatment. 